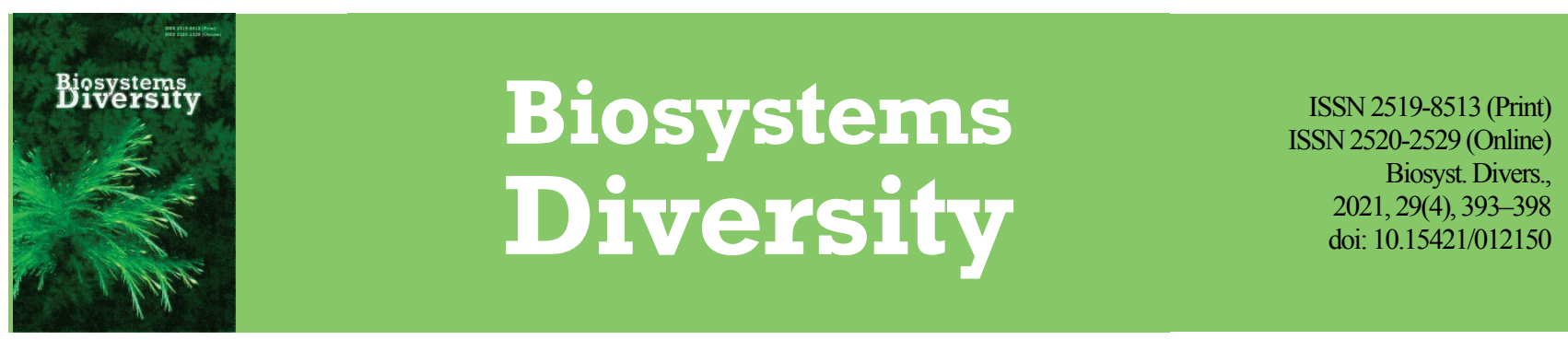

\title{
Water vole (Arvicola amphibious) as an object of long-term biomonitoring in a floodplain area (Western Siberia, Russia)
}

\author{
V. B. Ilyashenko*, E. M. Luchnikova*, A. V. Kovalevsky**** \\ *Kemerovo State University, Kemerovo, Russia \\ **Tomsk Agricultural Institute branch of Novosibirsk State Agrarian University, Tomsk, Russia
}

Article info

Received 02.11.2021

Received in revised form 05.12 .2021

Accepted 07.12.2021

Kemerovo State University,

Krasnaya st., 6,

Kemerovo, 650000, Russia

Tel.: +7-902-755-27-82.

E-mail:vadilj@yandex.ru

Tomsk Agricultural

Institute branch of Novosibirsk

State Agrarian University,

Karl Marx st., 19, Tomsk,

634050, Russia.

Tel.: +7-906-921-58-79.

E-mail:

passer125@yandex.ru

Ilyashenko, V. B., Luchnikova, E. M., \& Kovalevsky, A. V. (2021). Water vole (Arvicola amphibious) as an object of long-term biomonitoring in a floodplain area (Western Siberia, Russia). Biosystems Diversity, 29(4), 393-398. doi:10.15421/012150

The paper is devoted to the dynamics of the water vole population in the conditions of total deforestation of valley forests and their subsequent restoration. We analyzed the relative population of small mammals in the typical biotopes in the Tom River basin (Western Siberia) on the border of the forest-steppe and taiga zones. From 1978 to 2019, 1,139 water voles Arvicola amphibius (Linnaeus, 1758) (synonym of $A$. terrestris) were caught with 50-meter trapping grooves; for 788 individuals we assessed the condition of non-metric features (phenes) of the skull. It was found that changes in the population level are non-cyclical, while against the background of a generally low occurrence of the species in the region, the population level increased tenfold in some years. It was shown that such episodic population surges can significantly impact the structure of the community of small mammals. In the valley of the Tom River, the water vole prefers inhabit wet meadows and ecotone areas between the meadow and the dark coniferous taiga forest. During the years of population surges, the water vole intensely occupies new nesting sites due to the dispersal activity of young animals but at the same time retains the original biotopic preferences. Dispersal of the species takes place in waterlogged wetlands. Most of the animals caught during the peak of their numbers were young animals of late broods born from overwintered individuals. The conducted phenetic analysis revealed the heterogeneity of young animals during the population surge, which allowed us to assume the participation of several populations in the formation of the peak. In the final surge year, the surge was characterized by an extremely low percentage of participation in the breeding of young females and the appearance of a large number of weakened animals, which led to crisis in the species population and the disappearance of the water vole from the captures. The research shows that one cannot predict the success of this process at the current stage; therefore, after flooding, it is necessary to continue monitoring.

Keywords: dynamics; population; population outbreaks; cranial phenes; resettlement.

\section{Introduction}

The study of animal population dynamics is an element of the regionnal environmental monitoring system. The most interesting research is related to repetitive cycles of small mammals (Litvinov et al., 2013; Lukyanova, 2017; Bazhenov et al., 2019; Yakimova, 2021). An example of such cycles is the number of population surges of the water vole Arvicola amphibius (Linnaeus, 1758) in the valley of the middle course of the Tom River. Many scientific works are devoted to the changes in small mammal communities under the influence of various anthropogenic factors (Norrdal, 1995; Chernousova et al., 2014; Gallo et al., 2017; Luchnikova et al., 2020). Therefore, Balčiauskas \& Balčiauskienè (2021) considered successional processes in communities of small mammals in flooded meadows that have transformed into hayfields. There are also studies on the transformation of the coastal-swamp complex of small mammals and works assessing the impact of deforestation on populations of small mammals (Bogdziewicz \& Zwolak, 2014; Ofori et al., 2016, 2018; Ilyashenko et al., 2019; Sullivan et al., 2019). Only a few of the studies consider not only the negative effects of human activity but also the statuses of populations of small mammals (Raybuck et al., 2012; Attuquayefio et al., 2017; Ilyashenko et al., 2020). However, most studies are short-term; they do not examine population recovery processes. It is equally rare to find work that compares the state of small mammal communities before and after major interventions begin (Smith et al., 2020, Kovalevsky, 2021).

From this point of view, the situation in the Tom river valley during the construction of the Krapivinskoe water reservoir is of particular interest. Since 1976, continuous logging of floodplain forests has been carried out in the bed of the future water reservoir. In total, 42 thousand hectares of forests, mainly from the dark coniferous forests (i.e. dark coniferous fir or spruce forests) were cut down in the process of clearing the bed. For environmental and economic reasons, the flooding of the territory did not take place, the construction of the water storage reservoir was stopped, and the natural communities of the anthropogenically disturbed territory entered the stage of restoration succession. Moreover, the elimination of 20 rural settlements in the flood zone, and at the same time the almost complete cessation of agricultural activities (cultivation of fields and gardens, grazing, haymaking), led to a sharp decrease in the anthropogenic impact on meadow ecosystems. Currently, the territory is under a limited nature use regime, which has led to natural reforestation, overgrowth of arable land, hayfields and pastures (Ilyashenko et al., 2020).

The 40-year-old series of stationary observations allowed us to trace the dynamics of the number and status of populations of small mammals based on a large amount of materials. The research was conducted in the Krapivinsky district of the Kemerovo Region, in the vicinity of the Azhendarovo Biological Station of the Kemerovo State University $\left(54^{\circ} 45^{\prime} \mathrm{N}, 87^{\circ} 01^{\prime} \mathrm{E}\right)$, at the transition point of the forest-steppe of the Kuznetsk Depression to the dark coniferous taiga forests of the foothills and low mountains of the Kuznetsky Alatau (Fig. 1). The territory is characterized by various habitats, from coniferous forests to dry meadows. Special attention was paid to the extensive areas that have been anthropogenically disturbed during the preparation of the reservoir bed: overgrown cuttings on the site of forests of various types, nests on the site of the settlements, willow woodlands that appeared in meadows.

The water vole $A$. amphibius, a widespread and numerous rodent species in the South of Western Siberia, was selected as one of the objects of the biomonitoring (Ravkin et al., 2009; Gashev, 2013; Erdakov \& Litvinov, 2014; Evsikov et al., 2017). In the years of population outbreaks, the species is a mass pest of crops, acting as a significant vector of vector- 
borne diseases and parasites that are dangerous for human health. Therefore, in years of mass reproduction, the share of this species in the rodent community can reach $90 \%$, which leads to a decrease in the number of all other species, a reduction in the one nest, as a result, the alteration of the community's structure (Chechulin et al., 2005; Litvinov et al., 2013; Meulemans, 2020).

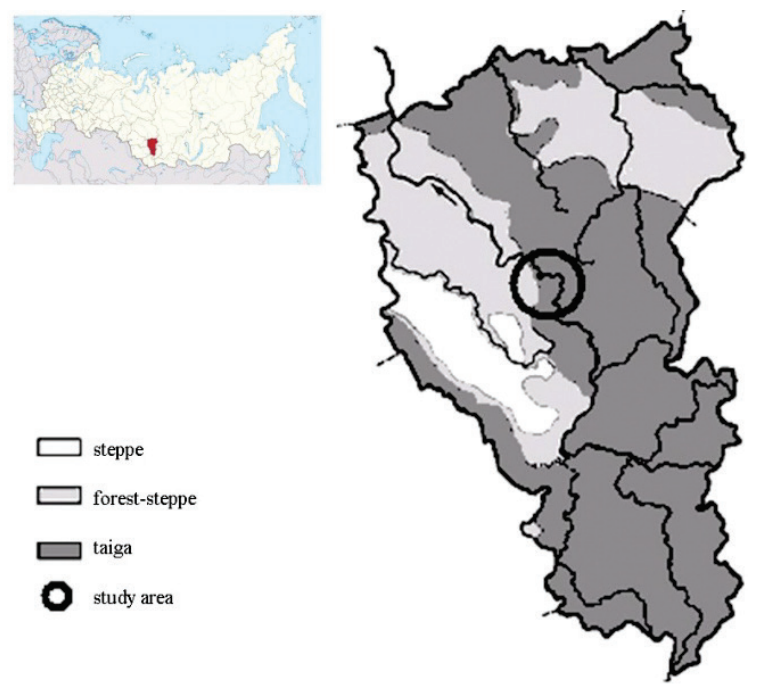

Fig. 1. Schematic map of the study area

In current conditions, it is necessary to monitor the number and status of populations of the species, especially in agriculture and healthcare. It should also be noted that A. amphibius is a model of the life form of a small burrowing mammal (Muzyka et al., 2010), which allows one to extrapolate the data obtained to species that occupy similar ecological niches. The paper aims to study population surges of the water vole based on the example of populations in the valley of the Tom River.

\section{Materials and methods}

The work with animals was conducted under the Protocol on the Ethics Commission of Kemerovo State University (February 15, 2018 No. 1). All the procedures were carried out in accordance with the International Guiding Principles for Biomedical Research Involving Animals from the Council for International Organizations of Medical Sciences.

We summarized the material on the water vole collected in the valley of the middle course of the Tom River for the period 1978-2019. Relative population estimates were carried out using a system of trapping grooves in the main biotopes of the area, including meadow areas in the dark coniferous taiga (or dark coniferous taiga) forests, mixed forests, overgrown wastelands on the site of agricultural land, and overgrown cuttings on the site of various types of forests. The small mammals were captured using 50-meter trapping grooves and then analyzed.

The total number of captured individuals was 1,139. Biotopic timing was estimated using the index of fidelity to biotopes proposed by Pesenko (1982), which is conventionally used in studies of small mammals (Ivanter et al., 2017; Ilyashenko et al., 2019, 2020; Ivanter, 2020). The index is calculated using the following formula:

$$
F_{i j}=\left(n_{i j} \times N-n_{j} \times N_{j}\right) /\left(n_{i j} \times N+n_{j} \times N_{j}-2 n_{i j} \times N_{j}\right),
$$

where $n_{i j}$ - the number of individuals of the $i^{\text {th }}$ species in the $j^{\text {th }}$ sample (biotope) with the $\mathrm{N}_{\mathrm{j}}$ volume, $\mathrm{n}_{\mathrm{i}}$ - the number of individuals of this species in all collections with the total $\mathrm{N}$ volume.

The value of the $\mathrm{F}_{\mathrm{ij}}$ indicator changes from " -1 " when the species is absent in a given habitat to " +1 " when the species occurs only there. A zero indicator indicates the indifference of the species to the given biotope (i.e., the species does not prefer it but does not avoid it either). If the timing indicators in all the studied biotopes were equal to zero or slightly $( \pm 0.25)$ deviate from it in one direction or another, then the species was classified as habitat generalists.

The state of non-metric features (phenes) of the skull were measured according to the scheme for the water vole proposed by Peskov \& Emelyanov (2001). When processing the material, we classified each speci- men according to the presence or absence of a specific non-metric feature: phene.

A total of 788 samples of skulls of the individuals caught in 20112016 were processed according to 36 characteristics, 34 of which were paired: 210 of these animals were caught in 2014, and 451 were obtained in 2015. For bilateral (paired) features, the asymmetry coefficient was calculated.

Mathematical data processing was performed using the Statistica 10 application software package (StatSoft Inc., USA, 2011).
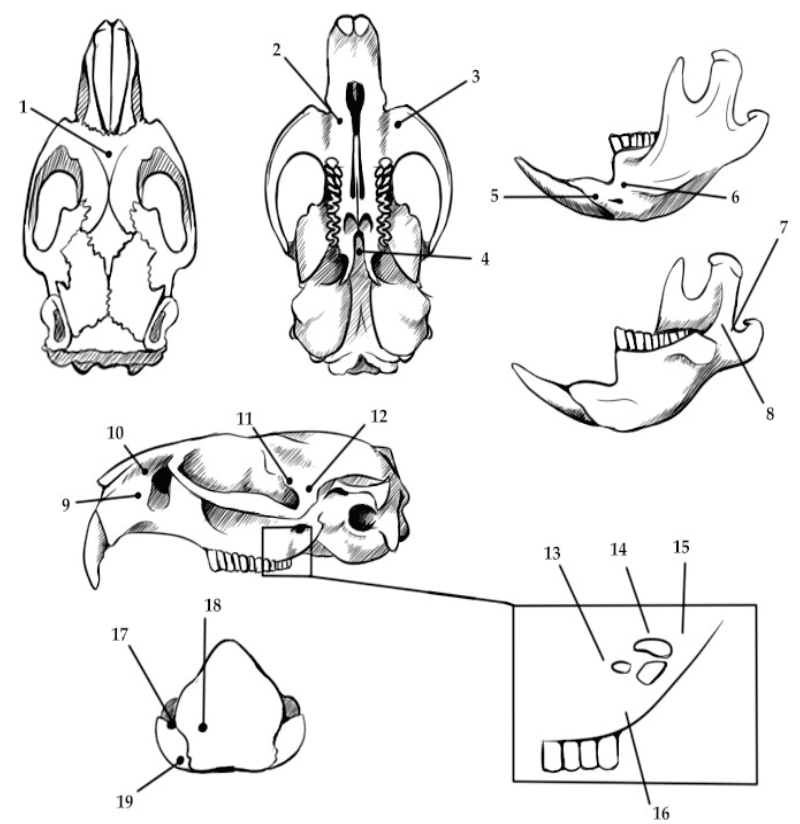

Fig. 2. Location of non-metric features on the skull of the water vole Arvicola amphibius according to Peskov \& Emelyanov (2000, 2001): 1 - large central frontal foramen; 2 - maxillary "pre-dental" foramen; 3-lateral maxillary foramen; 4 -medial foramen on the main sphenoid bone; 5 - lower lateral parotid foramen of the lower jaw; 6 -additional chin foramen; 7 - foramen in the gap between the angular and articular processes; 8 -large foramen on the incisor roller of the lower jaw (double numbering means that the sign is bilateral); 9 - anterior preorbital foramen; 10 - preorbital foramen in the maxillofacial suture; 11 -temporal foramen; 12 -additional temporal foramen; 13 -anterior accompanying foramen in the foramen ovale area; 14 - upper accompanying foramen in the foramen ovale area; 15 -accompanying foramen in the foramen ovale area; 16-lateral accompanying foramen in the foramen ovale area;

17 - upper condyle foramen; 18 -additional lateral sublingual opening; 19- lower condyle foramen

\section{Results}

In the Kemerovo Region, the water vole is found in the foothills of the Salair Ridge and the Kuznetsky Alatau, along the valley of the River Inya and the River Tom and their tributaries; it occurs the Kuznetsk Depression. Landscape populations living in the Kemerovo Region belong to the foothill-stream type (Panteleyev, 2001a). The animals inhabit grasslands and the marshy part of the valleys of rivers and streams, oxbow lakes and lakes. In the first half of the 20th century, the species was actively harvested for its skins. In the Kemerovo Region, the main area of water vole harvesting was in the middle course of the Tom River and above and along the Kondoma River. In the mid-1930s, more than 160 thousand skins of water vole were harvested in Gornaya Shoria (Tashtagolsky, Myskovsky, and Kuzedeyevsky districts). During mass reproduction of rodents, more than 160 thousand skins of water vole were harvested. There were no cases of mass reproduction of water vole throughout the north of the region.

In the Krapivinsky district, the species is not numerous; its share among rodent captures accounts for no more than 5\%. Near the Lachinovo Biological Station of the Kemerovo State University (54\%9' N, 
$87^{\circ} 00^{\prime} \mathrm{E}$ ), the species inhabits floodplain meadows, overgrown cuttings along the bank of the Tom River, and ecotones in the upper part of the valley slope of its tributary, the Stepovaya River.

Wet meadows and ecotones between the meadow and the dark coniferous taiga forest are the preferred biotopes for the water vole in the Azhendarovo permanent study area (Fig. 3).

Even though the habitat conditions are close to optimal for the water vole in the Tom River valley, the species is generally characterized by a low population. A series of floodplain lakes and extensive areas of swampy meadows and clearings at the foot of the Azhendarovo ridge contribute to the formation of isolated populations of water vole living on the periphery of the studied area. Perhaps, due to such negative factors directly at the hospital, only two periods of increased numbers can be distinguished during the 40 years of research on small mammals. The first one was observed in 1980 when the number of the specimens increased 5 times during the summer, but the next year it returned to the initial level (Fig. 4).

During this period, the water vole concentrated mainly on floodplain meadows (Fig. 5), penetrating the dark coniferous taiga forests and, to a minor extent, the cuttings.

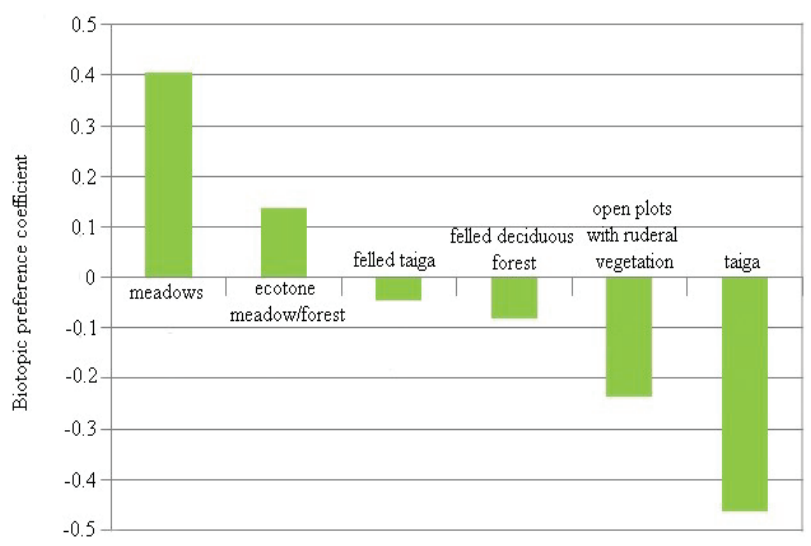

Fig. 3. The range of preferred water vole biotopes of the Tom River valley according to the data of the Azhendarovo biostation for 1978-2019

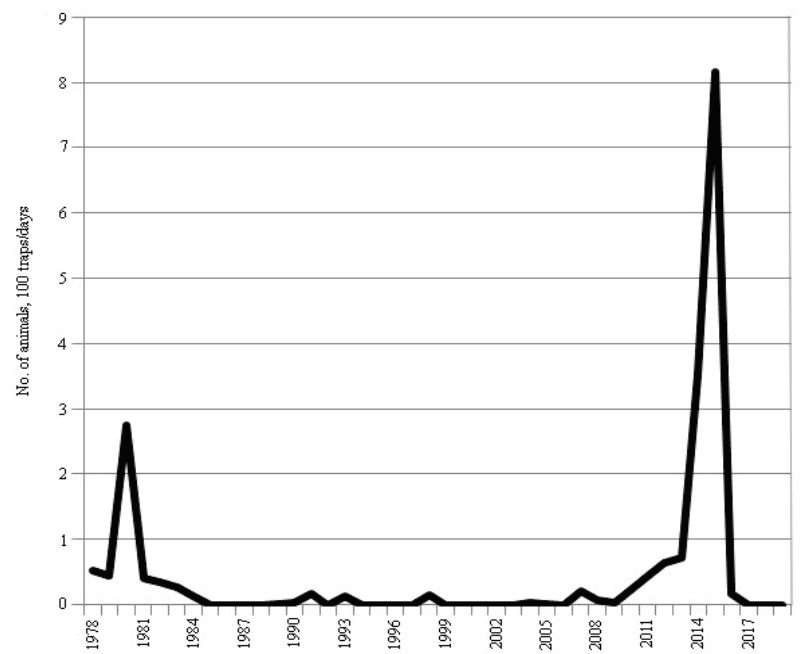

Fig. 4. Long-term population dynamics at the Azhendarovo permanent study area (Kemerovo Region, Krapivinsky district) based on the database of the Department of Zoology of Kemerovo State University for the period of 1978-2019

The second population surge began to be recorded in 2011, when the number also exceeded the multi-year level by 10 times; however, unlike the first surge, it was prolonged, peaking in 2015 and exceeding the average long-term values of the number by more than 40 times. The number of specimens caught during the season was 487 , which exceeds the results of 2014 by two times.

However, at the beginning of August, there was a sharp drop in the number of the studied species (Fig. 6). Cases of caught animals suffering diseases became more frequent; when kept in captivity, the animals usual- ly died within a day. The young showed no signs of puberty, which led to the collapse of the population. In 2016, only 12 specimens were caught, and in the next three years, not a single capture was recorded (Fig. 5): the water vole has completely disappeared from the catch.

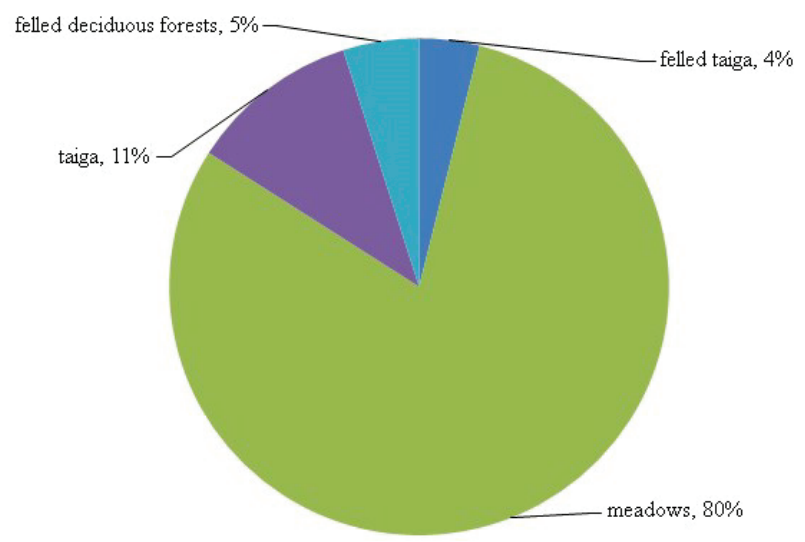

Fig. 5. Biotopic distribution of water vole in the valley of the middle course of the Tom River according to relative records at the Azhendarovo permanent study area for 1980

Biotopic distribution of the water vole during the second outbreak was significantly different from the first one. In 2015, significant dispersion of the population was observed across biotopes (Fig. 7), resulting in only a third of the population concentrating in grasslands, and the rest of the animals were widely dispersed across all the main biotopes of the area, including the dark coniferous taiga, overgrown cuttings on the site of the dark coniferous taiga, and mixed forests.

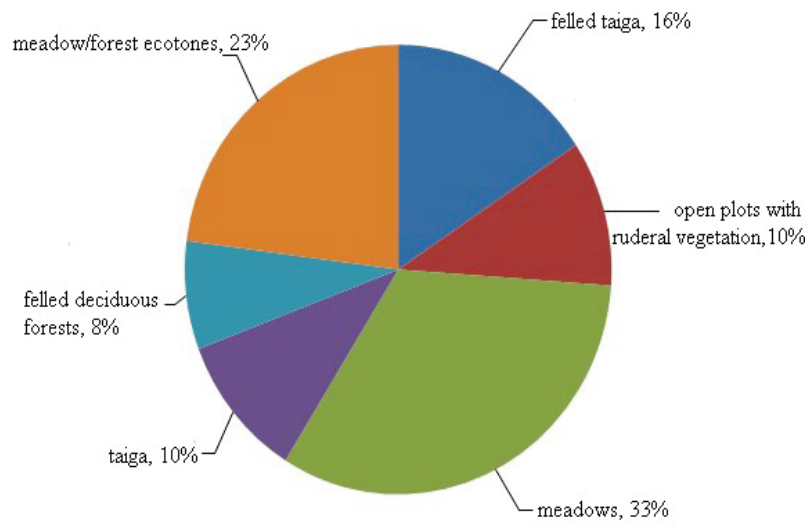

Fig. 6. Biotopic distribution of water vole in the valley of the middle course of the Tom River according to relative records at Azhendarovo permanent study area for 2015

The analysis of the phenetic heterogeneity of animals according to the data for 2011-2016 shows that although animals of the usual phenotype made up a significant proportion throughout the years of the study, the nature of deviations from it in animals captured in 2014 and 2015 was multidirectional.

The analysis of the contribution of individual phenes to the separation of samples in the space of canonical discriminant functions showed that the most significant were the phenes associated with the features of the mandible. Moreover, the frequency of the appearance of foramen was maximum in 2014 and minimum in 2015. In the predorbital foramen and the oval foramen area, on the contrary, the frequency of the appearance of the foramen in 2015 was significantly higher than in 2014 (Table 1).

Based on paired features, the asymmetry coefficients were calculated for each species and each year of capture (Table 2).

Significant differences according to the Student criteria were found when comparing the material for 2014 and 2015. They results showed the most pronounced differences in the level of asymmetry between the samples of animals captured in 2014 and 2015. Based on these data, we can conclude that in 2015, in addition to the original phenotypes of 2014, other, more asymmetric ones appeared. 


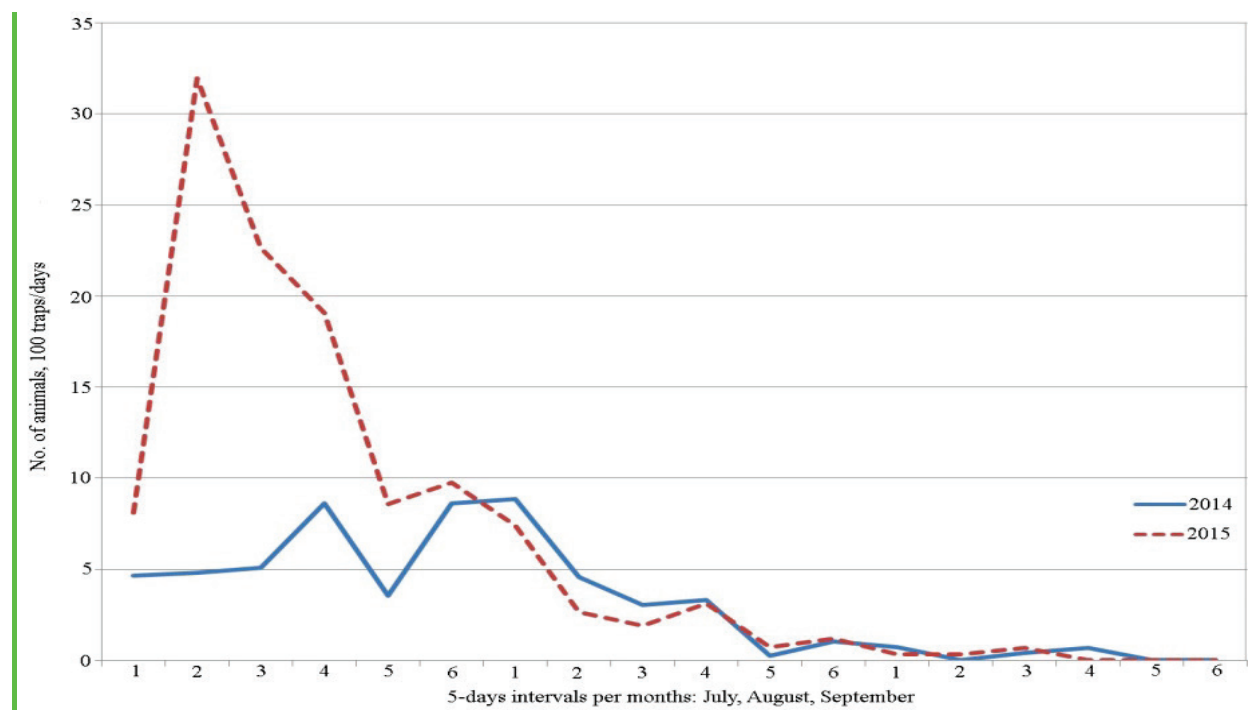

Fig. 7. Seasonal dynamics of the number of Arvicola amphibius at the Azhendarovo biological station in 2014-2015

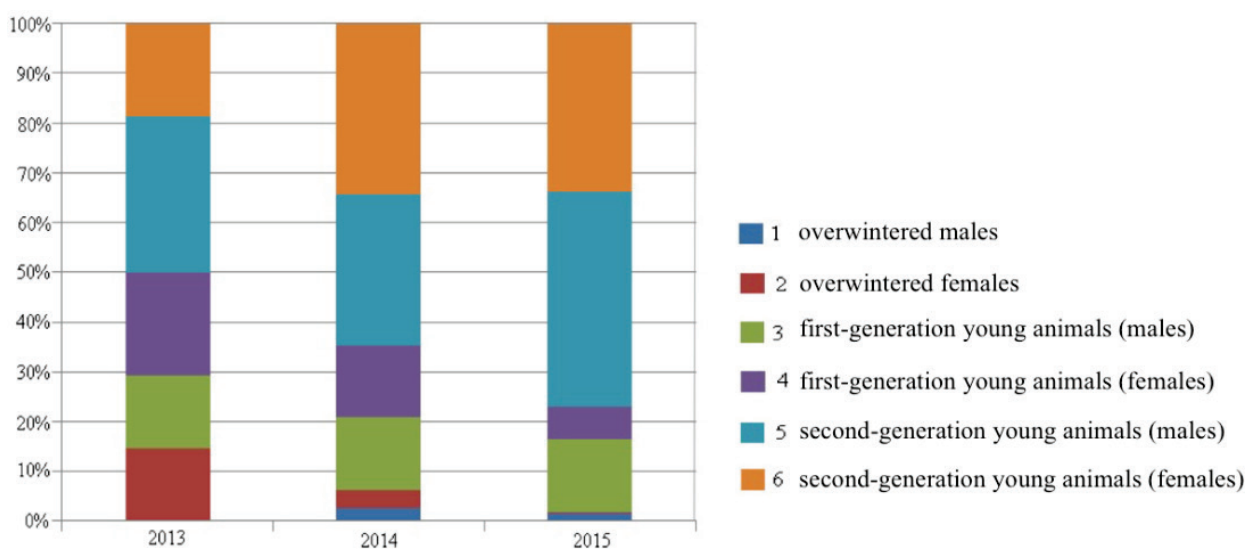

Fig. 8. Age and sex structure of Arvicola amphibius in the Tom River valley according to the records at the Azhendarovo Biological Station for 1978-2019

\section{Discussion}

In general, the biotopic preferences of the water vole in the study area are quite typical for Siberia. According to the material collected in other regions, primarily in the forest-steppe zone of the Novosibirsk Region, where long-term research was conducted, there occurred similar trends. Even small islands of deciduous forests are avoided by the water vole. The high number of the studied species in the Tom valley on the ecotone on the border with the dark coniferous taiga forest is all one of the most remarkable in our research. This trend is probably due to the fact that lowlying areas of aspen-fir forests have undergone significant waterlogging, which attracts the species under study. It avoids drier areas of the dark coniferous taiga (Panteleyev, 2001b, 2010).

The dynamics of the population of water voles in the study area has an outbreak character, noted by the researchers almost throughout the species range; however, it differs significantly from such in neighboring regions. Thus, for the forest-steppe zone of the north of the Novosibirsk Region, researchers marked a 24-year cycle of population fluctuations, for the wetlands of the Barabinskaya forest-steppe, a 10-year cycle is typical; in Yakutia, there is a short, 5-year cycle, and in the mountainous regions of Altai, there is a long cycle of 50 years. The external limiting factors for the existence of water vole populations are the hydrological conditions of habitats. Taking into account these trends, we expected to see similar results in the middle reaches of the Tom River (the study region) and downstream, in the taiga floodplains within the Tomsk Region. Nevertheless, we found that a clear 12-year cycle is manifested in the Tomsk Region, whereas in our studies, surges in water vole numbers were observed between the intervals of 35 years. Some studies show that in conditions of anthropogenic transformation, in particular, under the influence of agriculture, the natural rhythm of population dynamics and the nature of its peaks are disrupted (Nazarova \& Evsikov, 2012; Litvinov et al., 2013; Erdakov \& Litvinov, 2014; Evsikov et al., 2016; Meulemans, 2020).

It is worth noting the peculiar nature of the resettlement dispersion during the two mass surges of the population. In 1980, there was a significant increase in the numbers of voles in meadow biotopes, as happens in the Barabinskaya lowland (Erdakov \& Litvinov, 2014). In 2015, there was a clear pattern of redistribution, when the water vole was actively penetrating into the dark coniferous taiga forests. Other scientists also noted a similar pattern of partial penetration along the river valleys and the shores of the forest zone (Panteleyev, 2001b). The presence of wetlands is often a decisive factor for the resettlement of this species, especially in mountainous areas. This fact was emphasized by Panteleyev (2001b), who analyzed the range of the species in the Caucasus. From these standpoints, the deep penetration of a water vole through the swampy foothills of the Azhendarovo Ridge into the taiga does not seem to be something incredible.

We found that in 2013, most of the young animals were caught in a fairly narrow strip along the border of the clearing on the site of the dark coniferous taiga forest and swampy meadow. However, based on the distribution of breeding individuals, one can see that the points of their capture are shifted to the border between the clearing and the dark coniferous taiga forest. In 2014, adult animals were already noticed in a wider range of habitats, primarily inhabiting wet meadows. In 2015 , favourable conditions for the nesting of this species were preserved, and the water vole began to use the floodplain lakes of the Azhendarovo Basin more actively. The species occupied a more extensive set of habitats, reaching its maximum. The successful reproduction of the settled animals allowed the water voles to expand their range to all types of meadows and drier areas of the dark coniferous taiga. The settlement involved young animals who did not reach puberty. 
Table 1

Contributions of phenes to the distribution of specimens of Arvicola amphibius in the valley of the Tom River $\left(54^{\circ} 45^{\prime} \mathrm{N}, 87^{\circ} 01^{\prime} \mathrm{E}\right)$ in the space of the first two discriminant functions

\begin{tabular}{|c|c|c|c|c|}
\hline \multirow{2}{*}{$\begin{array}{l}\text { Phene } \\
\text { (feature) }\end{array}$} & \multicolumn{2}{|c|}{$\begin{array}{l}\text { First discriminant } \\
\text { function }\end{array}$} & \multicolumn{2}{|c|}{$\begin{array}{l}\text { Second discriminant } \\
\text { function }\end{array}$} \\
\hline & $\begin{array}{l}\text { structural } \\
\text { coefficients }\end{array}$ & t-test & $\begin{array}{c}\text { structural } \\
\text { coefficients }\end{array}$ & t-test \\
\hline $1^{*}$ & -0.035 & 0.977 & 0.148 & 4.198 \\
\hline $2 a^{* *}$ & -0.076 & 2.129 & 0.058 & 1.643 \\
\hline $2 b^{* *}$ & -0.061 & 1.707 & -0.013 & 0.364 \\
\hline $3 a$ & -0.145 & 4.121 & 0.076 & 2.133 \\
\hline $3 b$ & -0.069 & 1.925 & 0.027 & 0.762 \\
\hline 4 & -0.229 & 6.594 & 0.083 & 2.342 \\
\hline $5 a$ & -0.190 & 5.436 & 0.078 & 2.185 \\
\hline $5 b$ & -0.246 & 7.120 & 0.041 & 1.160 \\
\hline $6 a$ & 0.366 & 11.015 & 0.013 & 0.359 \\
\hline $6 \mathrm{~b}$ & 0.186 & 5.315 & -0.058 & 1.623 \\
\hline $7 \mathrm{a}$ & 0.426 & 13.194 & 0.031 & 0.858 \\
\hline $7 \mathrm{~b}$ & 0.476 & 15.193 & 0.045 & 1.250 \\
\hline $8 a$ & -0.020 & 0.549 & -0.056 & 1.574 \\
\hline $8 b$ & 0.026 & 0.717 & 0.841 & 43.517 \\
\hline $9 a$ & -0.083 & 2.335 & -0.041 & 1.142 \\
\hline $9 \mathrm{~b}$ & -0.284 & 8.292 & 0.045 & 1.269 \\
\hline $10 \mathrm{a}$ & -0.373 & 11.266 & 0.016 & 0.436 \\
\hline $10 \mathrm{~b}$ & -0.507 & 16.507 & 0.042 & 1.171 \\
\hline $11 \mathrm{a}$ & -0.209 & 5.999 & 0.034 & 0.949 \\
\hline $11 \mathrm{~b}$ & -0.128 & 3.619 & 0.026 & 0.742 \\
\hline $12 \mathrm{a}$ & -0.204 & 5.840 & 0.062 & 1.741 \\
\hline $12 \mathrm{~b}$ & -0.100 & 2.817 & -0.047 & 1.322 \\
\hline $13 a$ & -0.218 & 6.268 & 0.016 & 0.456 \\
\hline $13 b$ & -0.179 & 5.104 & -0.003 & 0.071 \\
\hline $14 \mathrm{a}$ & -0.186 & 5.315 & -0.043 & 1.194 \\
\hline $14 \mathrm{~b}$ & -0.267 & 7.760 & 0.060 & 1.687 \\
\hline $15 \mathrm{a}$ & -0.190 & 5.411 & -0.108 & 3.055 \\
\hline $15 b$ & -0.242 & 7.001 & 0.058 & 1.635 \\
\hline $16 a$ & -0.241 & 6.968 & 0.095 & 2.687 \\
\hline $16 \mathrm{~b}$ & -0.208 & 5.966 & 0.130 & 3.664 \\
\hline $17 \mathrm{a}$ & -0.141 & 4.006 & 0.136 & 3.838 \\
\hline $17 \mathrm{~b}$ & -0.019 & 0.528 & 0.103 & 2.900 \\
\hline $18 \mathrm{a}$ & -0.033 & 0.938 & 0.097 & 2.746 \\
\hline $18 \mathrm{~b}$ & 0.030 & 0.834 & 0.031 & 0.864 \\
\hline $19 \mathrm{a}$ & -0.143 & 4.062 & -0.001 & 0.017 \\
\hline $19 \mathrm{~b}$ & -0.049 & 1.385 & -0.027 & 0.745 \\
\hline $\begin{array}{l}\text { Discriminant } \\
\text { function }\end{array}$ & Eigenvalue $\lambda$ & $\begin{array}{c}\text { Percentage of } \\
\text { contribution }\end{array}$ & $\begin{array}{l}\text { Correlation } \\
\text { coefficient }\end{array}$ & $\chi^{2}$ \\
\hline $\begin{array}{l}\text { First discriminant } \\
\text { function }\end{array}$ & 0.3884 & 56.250 & 0.5289 & 343.56 \\
\hline $\begin{array}{l}\text { Second discrimi- } \\
\text { nant function }\end{array}$ & 0.1286 & 18.621 & 0.3375 & 94.709 \\
\hline
\end{tabular}

Note: *-unilateral feature; $*$ - bilateral feature.

Table 2

Statistical characteristics of the asymmetry of paired phenes of the skull of Arvicola amphibius over different years of research

\begin{tabular}{cccc}
\hline $\begin{array}{c}\text { Year of } \\
\text { observations }\end{array}$ & $\begin{array}{c}\text { Number } \\
\text { of specimens }\end{array}$ & $\mathrm{x} \pm \mathrm{SD}$ & $\begin{array}{c}\text { Variation } \\
\text { coefficient, \% }\end{array}$ \\
\hline 2011 & 25 & $0.212 \pm 0.111$ & 52.6 \\
2012 & 46 & $0.247 \pm 0.117$ & 47.6 \\
2013 & 44 & $0.243 \pm 0.099$ & 40.6 \\
2014 & 210 & $0.218 \pm 0.102$ & 46.8 \\
2015 & 451 & $0.256 \pm 0.110$ & 43.1 \\
2016 & 12 & $0.275 \pm 0.124$ & 45.0 \\
\hline
\end{tabular}

The water vole is believed to be one of the most actively reproducing rodents. In optimal conditions (the lower reaches of the Volga River), one overwintered female can produce up to seven broods during the summer. Unlike other species of voles, the intensity of reproduction of the first broods is not that great, but it is still quite significant. Therefore, about $38.4 \%$ of the females breed in the Novosibirsk Region. During the phase of population growth, some scientists noted a significant increase in the intensity of reproduction of young females and an increase in the mass of testes and seminal vesicles in male juveniles, which may be associated with prenatal maternal influence on the rate of sexual development of offspring (Panteleyev, 2001b, 2010; Nazarova et al., 2012, 2021). For the Azhendarovo population, cases of catching breeding young females were rare. Over the years of the development of the population surge, an increase in the number of young immature individuals compared to adults was observed. Thus, most of the animals caught during the surge were young animals of late broods of overwintered individuals (Fig. 6). This specificity of the sex and age structure leads to the increasing numbers in autumns. The sharp drop in numbers after the peak observed in the study area is generally characteristic of the species. Among the autoregulatory mechanisms, the scientists indicate the behavioural ones. According to the research in the Barabinskaya forest-steppe, water voles form local reproductive settlements, including potential competitors for food and reproductive resources. Therefore, a decrease or increase in aggression towards neighboring individuals is a condition for the relative stability of settlements and their effective preservation over time (Nazarova et al., 2012; Evsikov et al., 2016).

Autoregulatory mechanisms include a change in reproductive strategy against the background of a population surge. Thus, in 2016, there were no signs of puberty in young individuals, which lowered the reproductive capabilities of the population. Savchenko et al. (2014) also indicated an increase in embryonic mortality in water voles against the background of stress reactions of females, which are inevitable during overpopulation.

The increase in mortality from infectious diseases during outbreaks of the population also deserves attention. In our research in August 2016, cases of catching sick animals became more frequent. Similar information was given by Litvinov et al. (2013), when in the Novosibirsk Region, at the end of the population peak, corpses of water voles were everywhere, which has never happened at other phases of population dynamics. During these years, outbreaks of tularemia infection were recorded among the population of this region. A similar pattern was recorded for the Omsk Region (Litvinov et al., 2013; Yakimenko \& Dancing, 2017).

The prolongued 2014-2015 population surge is of interest. Presumably, the prolongation of the population peak and its unusual intensity can be explained by successive outbreaks in neighboring populations.

Phenetic analysis shows that the high number of water voles in 2015 was due not so much to the reproduction of animals with the original phenotype or animals born in 2014 as to the immigration of individuals with other features of the skull structure from nearby territories.

The nesting of the water vole took place in two stages and began in 2013-2014 with the animals inhabiting floodplain areas with numerous lakes. As a result of such breeding, they could encounter the water vole population inhabiting the swampy foothills of the ridge. In this case, the appearance of a large number of species with a different phenotype in 2015 should be considered as a response of one population to the invasion attempt by another.

Currently, there are plans to resume the construction of the Krapivinsky Reservoir and flood the research area. In the case of gradual flooding, the water vole can move to the non-flooded areas of the Tom River valley. Nonetheless, the success of this process will depend on many factors, including the waterlogging of land and the state of local communities of small mammals.

\section{Conclusion}

In the study area, the water vole mainly settles in swampy meadows and ecotone areas with high humidity and sufficient food supply. Animals avoid cluttered forest areas of cuttings, the dark coniferous taiga forests, as well as the mixed forests. The population dynamics of the species are characterized by periodic surges with annual peaks and a subsequent decrease in the number to the average annual value. There were 2 mass surges in the study area over 40 years. During the surge, there was increase in the number of young, immature individuals, which indicated the dispersal of young animals into the study area. This trend was also evidenced by the analysis of the asymmetry of the skull and its non-metric features. The introduction of animals into unusual habitats may cause the development of epizootic phenomena that lead to a sharp decline in the population of the species. If the construction of the reservoir is resumed, it will be necessary to continue monitoring of the settlement of water voles from the flooded floodplain. 
The paper was supported by the Russian Foundation for Basic Research (grant No. 20-44-420008) "Assessment of the biological diversity of animals in revegetated and self-growing areas previously disturbed by mining".

\section{References}

Attuquayefio, D. K., Owusu, E. H., \& Ofori, B. Y. (2017). Impact of mining and forest regeneration on small mammal biodiversity in the Western Region of Ghana. Environmental Monitoring Assess, 189, 237.

Balčiauskas, L., \& Balčiauskienė, L. (2021). Long-term changes in a small mammal community in a temperate zone meadow subject to seasonal floods and habitat transformation. Integrative Zoology, in print.

Bazhenov, Y. A. (2019). Population of small mammals in the vicinity of the torey lakes (Southeast Transbaikalia) during the dry climatic phase: Dynamics and connection with precipitation. Contemporary Problems of Ecology, 12(1), 23-33.

Bogdziewicz, M., \& Zwolak, R. (2014). Responses of small mammals to clearcutting in temperateand boreal forests of Europe: A meta-analysis and review. European Journal of Forest Research, 133, 1-11.

Chechulin, A. I., Guljaev, V. D., Panov, V. V., \& Krivopalov, A. V. (2005). Vliyaniye fazy chislennosti i demograficheskoy struktury populyatsii vodyanoy polevki na yeye zarazhennost' gel'mintami [Influence of the phase of abundance and demographic structure of the water vole population on its infection by helminths]. Parazitologiya, 39(5), 397-406 (in Russian).

Chernousova, N. F., Tolkach, O. V., \& Dobrotvorskaya, O. E. (2014). Small mammal communities in forest ecosystems affected by urbanization. Russian Journal of Ecology, 45(6), 490-497.

Erdakov, L. N., \& Litvinov, Y. N. (2014). Tsiklichnost' mnogoletnego khoda chislennosti v populyatsiyakh vodyanoy polovki (Arvicola terrestris L.) [The periodicity of long-term dynamics of the water vole (Arvicola terrestris L.)]. The Bulletin of Irkutsk State University, Series Biology, Ecology, 8, 40-48 (in Russian).

Evsikov, V. I., Muzyka, V. Y., Nazarova, G. G., Potapova, O. F., \& Potapov, M. A. (2017). Effect of hydrological conditions on reproduction rate and population structure of the European water vole Arvicola amphibious. Russian Journal of Ecology, 48(3), 290-293.

Evsikov, V. I., Muzyka, V. Y., Potapova, O. F., \& Potapov, M. A. (2016). The role of neighborhood relations in maintenance of the spatial-ethological structure of local settlements as exemplified by the water vole (Arvicola amphibius). Doklady Biological Sciences, 469(1), 167-169.

Gallo, T., Fidino, M., Lehrer, E. W., \& Magle, S. B. (2017). Mammal diversity and metacommunity dynamics in urban green spaces: Implications for urban wildlife conservation. Ecological Applications, 27(8), 2330-2341.

Gashev, S. N. (2013). Dinamika chislennosti melkikh mlekopitayushchikh i osobennosti yeye prognozirovaniya $\mathrm{v}$ ekologicheskom monitoringe [Population dynamics of small mammals and some peculiarities of its forecasting in environmental monitoring]. Tyumen State University Herald, 12, 140-150 (in Russian).

Ilyashenko, V. B., Luchnikova, E. M., Danilov, V. N., Kovalevsky, A. V., \& Zubko, K. S. (2020). Dynamics of mouse-like rodent communities in anthropogenically disturbed territories of the southeast of Western Siberia (Kemerovo region, Russia). Zoodiversity, 54(6), 487-492.

Ilyashenko, V. B., Luchnikova, E. M., Skalon, N. S., Grebentschikov, I. S., \& Kovalevsky, A. V. (2019). Long-term dynamics of small-mammal communities in anthropogenically disturbed territories in the South-East of West Siberia. IOP Conference Series: Earth and Environmental Science, 224, 012055.

Ivanter, E. V. (2020). K izucheniyu dinamiki chislennosti obyknovennoy burozubki (Sorex araneus) (opyt analiticheskogo obzora sostoyaniya problemy) [Population dynamics of the common shrew (Sorex araneus) (experience in an analytical review of the state of the problem)]. Biology Bulletin, 47, 844-853 (in Russian).

Ivanter, E. V., \& Kurhinen, J. P. (2017). Changes in rodent populations of Eastern Fennoscandia under the influence of anthropogenic transformations of boreal ecosystems. Biology Bulletin, 44, 1134-1150.

Kovalevskiy, A. V., Tarasova, I. V., Luchnikova, Y. M., Filippova, A. V., Voronina, L. A., Gashkov, S. I., Zubko, K. S., Smetanin, A. V., \& Yefimov, D. A. (2021). Lesnaya rekul'tivatsiya ugol'nykh otvalov s pozitsii sokhraneniya faunisticheskogo raznoobraziya Kuzbassa [Forest reclamation of the coal dumps from the perspective of preserving the fauna diversity on the example of the Kuznetsk Coal Basin]. Lesovedenie, 5, 509-522 (in Russian).

Litvinov, Y. N., Kovaleva, V. Y., Efimov, V. M., \& Galaktionov, Y. K. (2013). Cyclicity of the European water vole population as a factor of biodiversity in ecosystems of Western Siberia. Russian Journal of Ecology, 44(5), 422-427.

Luchnikova, E., Ilyashenko, V., Teplova, N., Kovalevsky, A., \& Zubko, K. (2020). Impact of agrocenoses on the populations of small mammals of recreational pine forests in the Tom River Valley. E3S Web of Conferences, 273, 10007.
Lukyanova, L. E. (2017). Formirovaniye chislennosti gryzunov v pirogennykh mestaobitaniyakh [Formation of the abundance of rodents in pyrogenic habitats]. Bulletin of Tomsk State University, Biology, 39, 172-189 (in Russian).

Meulemans, G. (2020). The swarming life of pastures: Living with vole outbreaks in the French Jura Uplands. European Association of Social Anthropologists, 28(3), 598-613.

Muzyka, V. Y., Nazarova, G. G., Potapov, M. A., Potapova, O. F., \& Evsikov, V. I. (2010). The effect of habitat hydrology on intraspecific competition, settlement structure, and reproduction in the water vole (Arvicola terrestris). Contemporary Problems of Ecology, 3(5), 606-610.

Nazarova, G. G., \& Evsikov, V. I. (2012). The evolutionary ecology of animal fertility: The fitness of progeny is determined by their prenatal development (according to the example of the European water vole, Arvicola terrestris L.). Russian Journal of Genetics: Applied Research, 2(1), 23-28.

Nazarova, G. G., Proskumyak, L. P., \& Yuzhik, E. I. (2021). Zavisimost' rosta i polovogo sozrevaniya vodyanykh polevok (Arvicola amphibius, Rodentia, Arvicolinae) ot sezona rozhdeniya i semeynykh faktorov [The growth and puberty of water voles (Arvicola amphibius, Rodentia, Arvicolinae) in relation to birth season and family factors]. Zoologicheskii Zhumal, 100(6), 660-670 (in Russian).

Norrdal, K. (1995). Population cycles in northern small mammals. Biological Reviews, 70(4), 621-637.

Ofori, B. Y., Attuquayefio, D. K., Owusu, E. H., Musah, Y., \& Ntiamoa-Baidu, Y. (2016). Spatio-temporal variation in small mammal species richness, relative abundance and body mass reveal changes in a coastal wetland ecosystem in Ghana. Environmental Monitoring and Assessment, 188(6), 330.

Ofori, B. Y., Garshong, R. A., Gbogbo, F., Owusu, E. H., \& Attuquayefio, D. K. (2018). Urban green area provides refuge for native small mammal biodiversity in a rapidly expanding city in Ghana. Environmental Monitoring and Assessment, 190(8), 480.

Panteleyev, P. A. (2001a). Obraz vida [Mode of life]. In: Panteleyev, P. A. (Ed.). Vodyanaya polevka: Obraz vida [The water vole: Mode of life]. Nauka, Moscow. Pp. 193-235 (in Russian).

Panteleyev, P. A. (2010). Rodentologiya [Rodentology]. KMK Scientific Press Ltd, Moscow (in Russian).

Panteleyev, P. A. (Ed.). (2001b). Vodyanaya polevka: Rezhim vida [The water vole: Mode of the lifes]. Nauka, Moscow (in Russian).

Pesenko, Y. A. (1982). Printsipy i metody kolichestvennogo analiza v faunisticheskikh issledovaniyakh [Principles and methods of quantitative analysis in faunal research]. Nauka, Moscow (in Russian).

Peskov, V. M., \& Emelyanov, I. G. (2000). Fenetika i fenogeografiya vodyanoy polevki (Arvicola terrestris) [Phenetics and phenogeography of the water vole (Arvicola terrestris)]. Vestnik Zoologii, 34(3), 39-44 (in Russian).

Peskov, V., \& Emelyanov, I. (2001). Cranium fenetuc. In: Panteleyev, P. A. (Ed.). Vodyanaya polevka: Obraz vida [The water vole: Mode of life]. Nauka, Moscow. Pp. 133-147 (in Russian).

Ravkin, Y. S., Bogomolova, I. N., \& Moskvitina, N. S. (2009). Classificational differences of small mammals' communities of Western Siberia. Tomsk State University Journal of Biology, 1(9), 42-58.

Raybuck, A. L., Moorman, C. E., Greenberg, C. H., DePerno, C. S., Gross, K. Simon, D. M., \& Warburton, G. S. (2012). Short-term response of small mammals following oak regeneration silviculture treatments. Forest Ecology and Management, 274, 10-16.

Savchenko, T. E., Nazarova, G. G., \& Evsikov, V. I. (2014). Differential sex-dependent postimplantation embryo mortality of the water vole (Arvicola amphibius). Doklady Biological Sciences, 454(1), 56-58.

Smith, C. K., Turner, A. J., Hiers, J. K., Garai, J., Wilson, W. N., \& Nicole, A. (2020). Nunley the effects of oak (Quercus) restoration on forest trajectory and small mammal use in the southern Cumberland Plateau, USA. Fire Ecology, 16(20), 621-637.

Sullivan, T. P., \& Sullivan, D. S. (2019). Similarity in occupancy of different-sized forest patches by small mammals on clearcuts: Conservation implications for red-backed voles and small mustelids. Mammal Research, 65, 255-266.

Yakimenko, V. V., \& Tantsev, A. K. (2017). K voprosu ob adaptivnom povedenii vodyanoy polevki Arvicola amphibius L. v periody zasukhi v ochagakh tulyaremii v Zapadnoy Sibiri [To the question of the adaptive behavior of the water vole Arvicola amphibius L. during periods of drought in hotbeds of tularemia in Western Siberia]. In: Obespecheniye epidemiologicheskogo blagopoluchiya: Vyzovy i resheniya [Securing epidemiological well-being: Challenges and solutions]. Nauka, Moscow. Pp. 147-189 (in Russian).

Yakimova, A. E., \& Gaidysh, I. S. (2021). The species composition and abundance of terrestrial small mammals in the Finnish-Russian friendship nature reserve. Nature Conservation Research, 6(S1), 127-136 (in Russian). 